\title{
Students' Perceptions Of The Full-Day School Application: Its Relationship Toward Science Learning Motivation
}

\author{
Insar Damopolii ${ }^{1 *}$, Hengky L. Wambrauw ${ }^{2}$, Siti Mutmainah ${ }^{3}$ \\ 1,2,3 University of Papua, Manokwari, Indonesia \\ *Corresponding author: i.damopoli@unipa.ac.id
}

\begin{abstract}
Students' perceptions about full-day school (FDS) on student learning motivation have been widely studied. However, the relationship found is moderate. Moreover, its relationship with science learning motivation has not been optimally studied. The research paper was aimed to reveal the relationship between students' perceptions of full-day school and motivation to learn science. The correlational method was used in this research. Respondent was 87 learners taken from an Islamic Junior high school in Manokwari. Validated questionnaires were used to measure perception and motivation. Simple regression was used to calculated data. The findings showed that $\mathrm{P}<0.5$, rxy $=0.726$, and $\mathrm{R}$ square $=0.527$. The findings reveal a strong relationship between students' perceptions of FDS on motivation to learn science. The application of FDS in schools has contributed to the students' motivation to learn science. Scheduling science learning needs to consider motivating students to learn in science.
\end{abstract}

Keywords: Full-day School, Science Learning, Student Motivation

$\begin{array}{ll}\text { History: } & \\ \text { Received } & : \text { 15 January } 2021 \\ \text { Revised } & : 1 \text { February } 2021 \\ \text { Accepted } & : 26 \text { March } 2021 \\ \text { Published } & : 25 \text { April } 2021\end{array}$

Published : 25 April 2021

\section{Introduction}

Full-Day School (henceforth FDS) is an alternative to solve education problems in Indonesia. FDS means an education system that implements a full day of learning or teaching and learning activities starting at 07.00-15.00. Based on researchers' observations at one of the Islamic junior high schools in Manokwari, FDS has been implementing. This school's curriculum combines the national curriculum, the school curriculum, and the Islamic curriculum (Said et al., 2018). The implementation of FDS is carrying out in three phases, namely the learning phase, the resting phase, and the habituation phase. The learning phase is like learning that is carrying out in general. The rest phase is carrying out twice. The habituation phase is Islamic habituation, such as prayer, eating, and reading the Al-Qur'an. The students' ability did not differ when they studied in FDS and half-day (Heagle et al., 2017). Even FDS is better than Half Day (Said et al., 2018). Students' academic ability increases when schools extend the hours of study (Battistin \& Meroni, 2016; Figlio et al., 2018). FDS has a positive influence on students in the long term (Atteberry et al., 2019). Even FDS provides long-term benefits for student development (Brownell et al., 2015).

FDS has a relationship with children's school attendance (Gottfried, 2017). Students will go to school if they have a strong desire. The strong desire of students is due to the excellent learning conditions provided by the school. This condition depends on their positive attitude. A positive attitude has a good effect on student motivation (Løvoll et al., 2017). 
Because creating conditions that build positive attitudes of students is necessary, ultimately, it can motivate students to learn. Motivation is related to science learning outcomes (Damopolii et al., 2018; Paramitha et al., 2016; Radyuli et al., 2020) to solve problems (Putra et al., 2019). Educational programs such as FDS, learning processes, and creative learning approaches in applying FDS make student learning motivation useful (Bathgate \& Schunn, 2017; Krisnayanti et al., 2020; Surinati et al., 2020).

The results of other research show that the implementation of FDS does not prevent students from increasing their learning achievement (Tran \& Pasquier-Doumer, 2019), even though FDS has a positive effect on school readiness (Felfe \& Zierow, 2018). Therefore, the three aspects of attention, motivation and readiness development are closely related to the achievement of FDS. If they lack focus, students' preparation may decrease, they cannot handle independent learning schedules at home, and they cannot complete tasks correctly due to exhaustion (Rahmatika \& Suyatno, 2020). However, more time spent in school does not necessarily mean better, and any expansion of the FDS program needs to be carefully considered in the context of the program (Leow \& Wen, 2017).

However, in reality, the implementation of FDS has not gone as expected. Many factors inhibit FDS from becoming ineffective. The implementation of FDS has an impact on students' psychology and cognition and their teachers (Hidayanti, 2018). Students feel overloaded by a large number of subjects in FDS (Suyatno \& Wantini, 2018). FDS causes conflicts for schools; even students and teachers become tired (Listiningrum et al., 2019; Nelwati et al., 2020). The results of the author's observations found that inappropriate schedule settings caused students to be less enthusiastic about implementing the program. Science lessons are to schedule at noon. Students are tired of following classes. Entering $01.30 \mathrm{pm}$, they began to show an uncomfortable attitude, looking lazy, bored, and sleepy. As a result of these problems, students' responses were different and formed different perceptions about the application of FDS. Students are tired of doing assignments because they have been studying all day.

Indeed, children's fatigue increases in FDS (Cooper et al., 2010), but improving their school activities will overcome boredom and fatigue in FDS. Teachers must know whether their students benefit or not from the FDS program (Gullo, 2000). Improvements can be made to the classroom atmosphere, make students comfortable, and extend the time to complete assignments (Madjid, 2018). School children are motivated to study with longer study time (Atteberry et al., 2019). A practical learning experience for students is one element that needs to consider in implementing FDS (Reynolds et al., 2014). Scheduling time in schools plays a vital role in encouraging student motivation (Benner \& Partelow, 2017). However, the student's motivation has not been a measurement concern (Reynolds et al., 2014). Motivation has a relationship with learning outcomes (Setiawan et al., 2020; Singh, 2011). Students will learn if they are motivated (Saptono et al., 2020). Teaching and school environmental factors have a role in students' motivation (Utomo et al., 2019).

Most of the teachers agreed with the implementation of FDS, but it was different from their students' responses (Hardianti et al., 2018). Although in fact, there are students who give good perceptions (Syafitri, 2020). There is no direct effect of FDS on student learning outcomes, but FDS affects learning motivation (Dani, 2019; Wahyuni et al., 2018). There is a moderate relationship between FDS and students' motivation at Islamic Junior High School, but its contribution is $19.2 \%$ (Muti'ah \& Sholeh, 2020). Other researchers found that this is 34\% (Rahman, 2018; Rosalina, 2012). On the other hand, students' motivation to learn science has decreased (A. E. Gottfried, 2019). Motivation in science is closely related to the school environment (Józsa et al., 2017). Given that the motivation to learn science is crucial to be considered by schools as a determining factor for student success. Students' success proves that the school is successful in running its educational program; on the other hand, if 
students fail, it indicates that the school's program has not been successful, and there is a need for change. Indeed, a school environment that implements FDS can motivate students at different levels. On the other hand, students' perceptions of FDS are different. Thus, research on the relationship between students' perceptions of FDS and learning motivation is needed, particularly in science learning. Our research aimed to reveal the relationship between students' perceptions of FDS and motivation to learn science.

\section{Materials and Methods}

The correlation method was used in this research. This method was to reveal the relationship between the two variables (see figure 1). Students' perceptions of the full-day school application were the independent variable (X). Motivation to learn science was the dependent variable (Y). A total of 87 students from an Islamic junior high school in Manokwari were the research respondent. Class VII consists of 39 students (Boys $=18$, Girls $=21$ ), class VII was 23 students (Boys $=14$, Girls $=9$ ), and class IX was 25 students (Boys = 10 , Girls $=15)$. The total number of boys was 42 , and the total of girls was 45 .

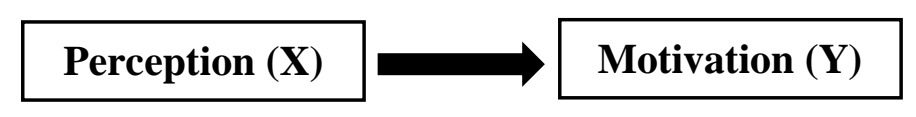

Figure 1. Relationship between perception and motivation

A questionnaire was to use as the data collection instrument. There were 30 questionnaires for students' perceptions of the full-day school system. The science learning motivation questionnaire consisted of 32 statements. The perception and motivation questionnaire was to validate twice. Experts did the first validation, and the second validation was to test on 53 students outside the respondents. The experts' results of the validation stated that the perception and motivation questionnaire was valid. The testing results on 53 students found 20 valid statements of perception questionnaire, 25 reports of valid motivation questionnaire.

The product-moment correlation was to use for validation testing. Reliability testing using the Cronbach alpha formula obtained a perception questionnaire of 0.805 (reliable) and a motivation questionnaire of 0.847 (reliable). Research questionnaire in the google form. Google Forms was used to make data collection easier. Sixteen students (eight boys and eight girls) were selected to gather answers about the science lesson schedule. They were a response to an online form to choose the right time for science lessons. Class hours are divided into five times based on eastern Indonesia, namely 07.30 - 08.5 (I), 09.00 - 10.00 (II), 10.30-11.50 (III), 13.00 - 14.10 (IV), and 14.20 - 15.30 (V).

The data collected was calculated and divided into five categories. The categories are very less (0 - 39), less (40 - 59), moderate (60 - 69), good (79 - 79), and excellent (80 - 100). The subsequent analysis was normality using Kolmogorov Smirnov. The regression analysis was used to reveal the relationship between students' perceptions of the full-day school system on science learning motivation.

\section{Results and Discussion \\ Results \\ Categories Of Students' Perceptions About Full-Day School And Motivation}

This research revealed the relationship between students' perceptions (P) of implementing full-day school and motivation (M) to learn science. Students have given different responses. Figure 1 reveals the categories of both students' perceptions and motivation. 


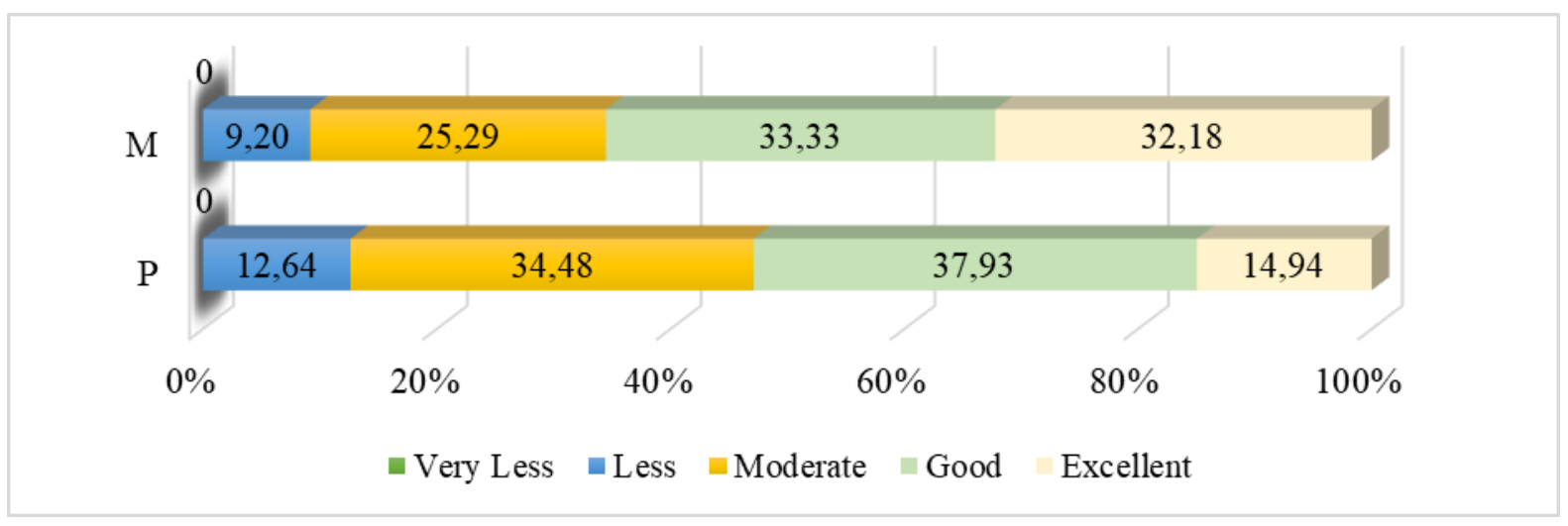

Figure 2. Graph of the students' perceptions and motivation to learn science

It can be seen in Figure 2 that there are perceptions and motivations of students that are included in the less to moderate category. The students' perceptions about the FDS system were $47.13 \%$, while the motivation to learn science was $34.48 \%$. This data shows that not all students have given a good perception of the application of FDS. This problem also occurs in students' motivation to learn science. Then, the relationship between these two variables is testing. Before testing, a normality test is required. One-Sample Kolmogorov-Smirnov Test for normality of data results is data are typically distributed $(\mathrm{P}>0.05)$. The results of this normality test indicate that regression testing can use. Tables 1 - 3 show simple regression testing.

Table 1. ANOVA Summary of the Linkages Between Student Perception of Fds Application on Science Learning Motivation

\begin{tabular}{llccccc}
\hline & Model & Sum of Squares & df & Mean Square & F & P \\
\hline \multirow{3}{*}{1} & Regression & 4819.924 & 1 & 4819.924 & 94.786 & $0.000^{\mathrm{b}}$ \\
& Residual & 4322.306 & 85 & 50.851 & & \\
& Total & 9142.230 & 86 & & & \\
\hline
\end{tabular}

Table 1 reveals a relationship between student perception of FDS application of science learning motivation $(\mathrm{P}<0.05)$. Thus, the perception of full FDS application is a predictor for science learning motivation.

Table 2. The regression Coefficient of the Linkages Between Students' Perception of Fds Application on Science Learning Motivation

\begin{tabular}{|c|c|c|c|c|c|c|}
\hline \multirow[t]{2}{*}{ Model } & & \multicolumn{2}{|c|}{$\begin{array}{l}\text { Unstandardized } \\
\text { Coefficients }\end{array}$} & Standardized Coefficients & \multirow[t]{2}{*}{$\mathrm{t}$} & \multirow[t]{2}{*}{$\mathrm{P}$} \\
\hline & & $\mathrm{B}$ & Std. Error & Beta & & \\
\hline \multirow{2}{*}{1} & (Constant) & 23.554 & 5.309 & & 4.437 & 0.000 \\
\hline & Perception & 0.916 & 0.094 & 0.726 & 9.736 & 0.000 \\
\hline
\end{tabular}

Table 2 show $\mathrm{P}<0.05$. It reveals that the relationship between student perception of FDS implementation on science learning motivation is significant. The model $\mathrm{y}=23.554+$ $0.094 \mathrm{X}$ is the regression model. It assumes that each increase in one perception value increases students' science learning motivation by 0.094 . 
Table 3. Regression Summary of The Relationship Between Students' Perception of the FullDay School Program on Science Learning Motivation

\begin{tabular}{ccccc}
\hline Model & $\mathrm{R}$ & $\mathrm{R}^{2}$ & Adjusted $\mathrm{R}^{2}$ & Std. Error of the Estimate \\
\hline 1 & $0.726^{\mathrm{a}}$ & 0.527 & 0.522 & 7.13096 \\
\hline
\end{tabular}

The R-value in Table 3 was 0.726 . It revealed that there was a strong relationship between students of FDS implementation on science learning motivation. R square is 0.527 , which tells that the contribution of the full-day school system's perception towards science learning motivation was $52.7 \%$.

\section{Student Responses About Scheduling Science Learning}

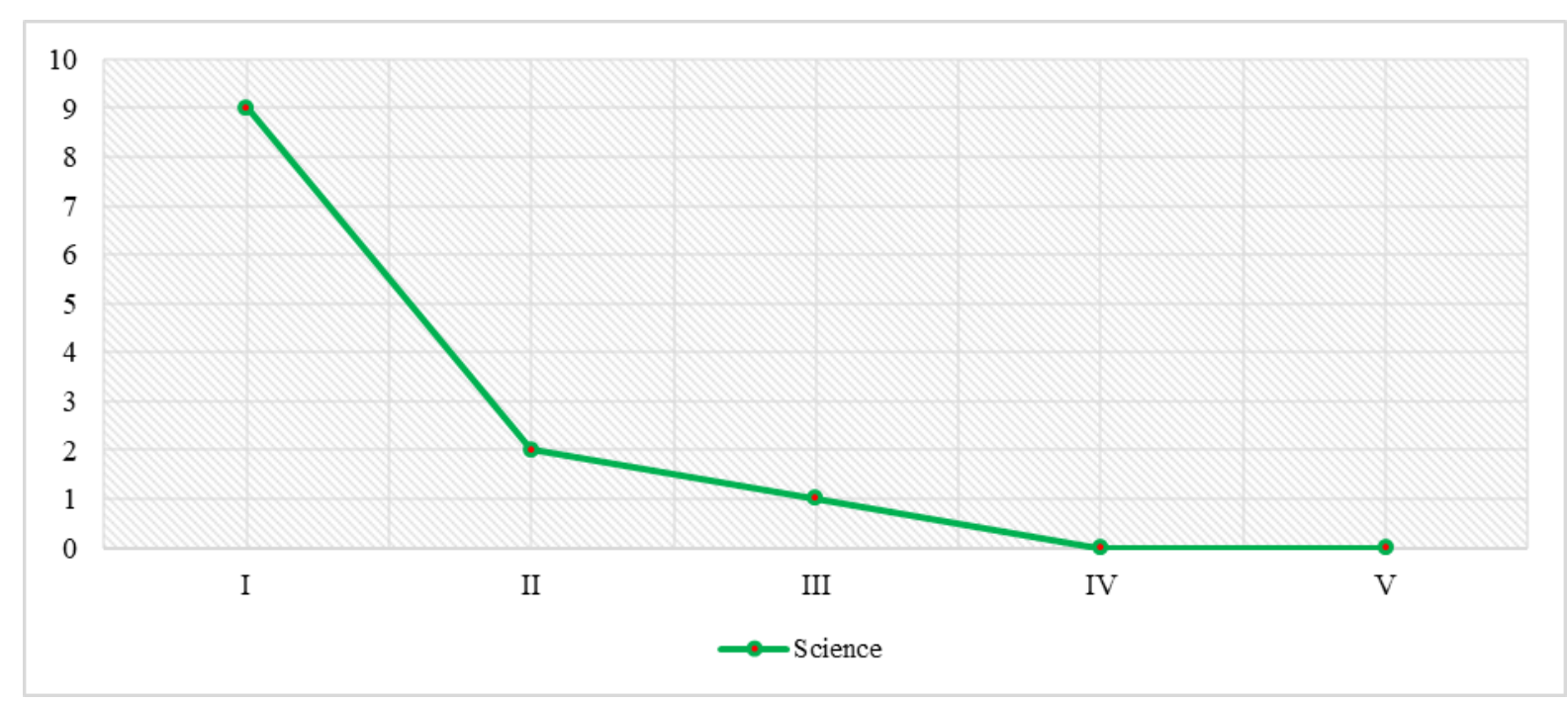

Figure 3. Student responses to scheduling science learning

Based on 16 respondents' responses in the figure, science learning is more precisely schedule in the morning between 07.30 - $11.50 \mathrm{am}$. There are no students who have a science learning schedule other than that time.

\section{Discussion}

Based on the research findings, it is revealing that students' perception of FDS implementation has a relationship with science learning motivation. The strength of the relationship between the two variables is a strong category. Indeed, students' perceptions have reached 52.7 in their contribution to learning science motivation, but other factors influence $47.3 \%$. The study results complement the previous research, which found a moderate relationship between FDS and students' learning motivation at Islamic Junior High School. Still, the contribution is only 19.2\% -34\% (Muti'ah \& Sholeh, 2020; Rahman, 2018; Rosalina, 2012). The author's findings prove that students' perception of FDS implementation has a strong relationship with motivation, particularly motivated to learn science.

Our findings reveal that it is necessary to consider students' perceptions of students' motivation to learn science. Students consider implementing FDS to be good, although not all of them give good responses. Likewise, with student learning motivation, there are still students who are not well motivated to learn science. The problems that have been expressed initially are boredom, fatigue in doing assignments, and scheduling of science subjects in applying FDS to be some of the factors for the lack of students' motivation to learn science. 
School plays a role in improving students' motivation (Morgan et al., 2017). A conducive learning environment and interest and need for learning make students motivated to learn (Iswardhani \& Djukri, 2015). The implementation of FDS needs to be regulated again so that students' learning comfort can fulfill. Motivation arises because students enjoy learning (A. E. Gottfried, 2019). The application of FDS must indeed control science learning. Student complaints about scheduling science subjects on the application of FDS need to be considered. This complaint makes their motivation decrease. When we tried to dig further information on 16 students, data was obtained, as shown in Figure 3.

Based on 16 respondents' responses in the figure, science learning is more precisely schedule in the morning between 07.30 - $11.50 \mathrm{am}$. There are no students who have a science learning schedule other than that time. It is a recommendation for schools with a full-day school implementation. Scheduling time in schools plays a vital role in encouraging student motivation (Benner \& Partelow, 2017). Studying student psychology and the length of study hours need to consider applying to a full-day school (Winurini, 2016). The proper scheduling for science lessons makes students interested in learning. Students' learning success increases when learning succeeds in attracting their attention. To attract students' attention, the school tries to make a science learning schedule according to their learning needs. The scheduling of science learning that has been on the afternoon schedule needs to reschedule in the future.

By paying attention to the learning schedule according to students' wishes, it helps to improve their motivation to learn well. The encouragement to learn comes from within them because the lesson schedule is in line with their expectations. Inner encouragement is a form of intrinsic motivation. Have inner motivation, motivation to learn science can be enhanced (Schumm \& Bogner, 2016). School scheduling contributes to student activities, especially student activities on FDS (Kain et al., 2017). Student boredom with scheduling time in implementing FDS is something that needs to be a focus of attention. Students are not motivated because they are not interested in learning. The division of time also affects the motivation time (Hidajat et al., 2020). This is to reduce student boredom and fatigue while studying during the FDS program. Boredom and obnoxiousness are indicators that affect the decline in learning motivation (Stoeber et al., 2011). If the scheduling of science lessons were placed in the afternoon, this would not match students' expectations of attending science lessons in the morning. The non-conformity with their expectations causes their low ability to follow the science learning process. The low ability to participate in the learning process causes a decrease in learning motivation (Anwar et al., 2020). The conditions that cause this problem need to be reviewed and changed by the school. Providing a school schedule, especially science lessons with the needs of students, is crucial. Teaching and learning are at the core for them to study science diligently. Indentation is one indicator of motivation to learn science; diligently studying and following the learning process, learning towards science will be good.

\section{Conclusion}

Based on the findings and exposure to the results and discussion, this research concluded a strong relationship between students' perceptions of FDS application on science learning motivation. This research recommends that schools can adjust the schedule of subjects according to the weight of the subjects. The ease and comfort of students in learning on the application of FDS have a good impact on their learning motivation.

\section{Acknowledgments}

The author thanks the Department of Biology Education, Universitas Papua, for funding the publication of this article. 


\section{References}

Anwar, K., Asari, S., Husniah, R., \& Asmara, C. H. (2020). Students' Perceptions of Collaborative Team Teaching and Student Achievement Motivation. International Journal of Instruction, 14(1), 325-344. https://doi.org/10.29333/IJI.2021.14119A.

Atteberry, A., Bassok, D., \& Wong, V. C. (2019). The Effects of Full-Day Prekindergarten: Experimental Evidence of Impacts on Children's School Readiness. Educational Evaluation and Policy Analysis, 41(4), 537-562. https://doi.org/10.3102/0162373719872197.

Bathgate, M., \& Schunn, C. (2017). The psychological characteristics of experiences that influence science motivation and content knowledge. International Journal of Science Education, 39(17), 2402-2432. https://doi.org/10.1080/09500693.2017.1386807.

Battistin, E., \& Meroni, E. C. (2016). Should we increase instruction time in low achieving schools? Evidence from Southern Italy. Economics of Education Review, 55, 39-56. https://doi.org/10.1016/j.econedurev.2016.08.003.

Benner, M., \& Partelow, L. (2017). Reimagining the School Day: Innovative Schedules for Teaching and Learning. Center for American Progress.

Brownell, M. D., Nickel, N. C., Chateau, D., Martens, P. J., Taylor, C., Crockett, L., Katz, A., Sarkar, J., Burland, E., \& Goh, C. Y. (2015). Long-term benefits of full-day kindergarten: a longitudinal population-based study. In Early Child Development and Care (Vol. 185, Issue 2, pp. 291-316). https://doi.org/10.1080/03004430.2014.913586.

Cooper, H., Allen, A. B., Patall, E. A., \& Dent, A. L. (2010). Effects of full-day kindergarten on academic achievement and social development. Review of Educational Research, 80(1), 34-70. https://doi.org/10.3102/0034654309359185.

Damopolii, I., Lefaan, P. T., \& Manga, M. (2018). Hubungan Motivasi Belajar dengan Hasil Belajar Biologi Siswa Di SMP 21 Rendani Manokwari. Prosiding Seminar Nasional Pendidikan Biologi, 1(1), 427-430. https://osf.io/preprints/inarxiv/wsvek/.

Dani, O. U. (2019). The Influence of Full Day School Learning Methods on Student Motivation in Grade XI of SMA Negeri 1 Plemahan, Kediri with Emotional Intelligence as a Moderator. Arilangga Development Journal, 3(2), 98-117.

Felfe, C., \& Zierow, L. (2018). From dawn till dusk: Implications of full-day care for children's development. Labour Economics, 55(October), 259-281. https://doi.org/10.1016/j.labeco.2018.10.006.

Figlio, D., Holden, K. L., \& Ozek, U. (2018). Do students benefit from longer school days? Regression discontinuity evidence from Florida's additional hour of literacy instruction. Economics of Education Review, 67, 171-183. https://doi.org/10.1016/j.econedurev.2018.06.003.

Gottfried, A. E. (2019). Academic Intrinsic Motivation: Theory, Assessment, and Longitudinal Research. In A. J. Elliot (Ed.), Advances in Motivation Science (1st ed., Vol. 6). Elsevier Inc. https://doi.org/10.1016/bs.adms.2018.11.001.

Gottfried, M. A. (2017). Does Absenteeism Differ for Children with Disabilities in Full-Day versus Part-Day Kindergarten?1. Journal of Education for Students Placed at Risk, 22(4), 260-281. https://doi.org/10.1080/10824669.2017.1388172.

Gullo, D. F. (2000). The long term educational effects of half-day vs full-day kindergarten. Early Child Development and Care, 160(1), 17-24. https://doi.org/10.1080/0030443001600102.

Hardianti, Haris, H., \& Mustari. (2018). Persepsi guru Dan Siswa Terhadap Penerapan Lima 
Hari Sekolah (Full Dat School) di SMK N 1 Pinrang. Jurnal Tomalebbi, 5(1), 123130. https://ojs.unm.ac.id/tomalebbi/article/view/6770.

Heagle, K., Timmons, K., Hargreaves, F., \& Pelletier, J. (2017). The social kindergartener: comparing children's perspectives of full- and half-day kindergarten. Early Child Development and Care, 187(5-6), 978-989. https://doi.org/10.1080/03004430.2016.1199551.

Hidajat, H. G., Hanurawan, F., Chusniyah, T., \& Rahmawati, H. (2020). Why i'm bored in learning? Exploration of students' academic motivation. International Journal of Instruction, 13(3), 119-136. https://doi.org/10.29333/iji.2020.1339a.

Hidayanti, M. (2018). Implementing Full Day School in Indonesia: "Analysing Impacts on Students, Teachers, and School Stakeholders." IJAEDU- International E-Journal of Advances in Education, IV(10), 127-134. https://doi.org/10.18768/ijaedu.419515.

Iswardhani, N., \& Djukri. (2015). Pengaruh Penggunaan Limbah Tapioka Sebagai Sumber Belajar Terhadap Motivasi Dan Hasil Belajar Siswa. Cakrawala Pendidikan, 34(1), 149-159. https://doi.org/10.21831/cp.v1i1.4185.

Józsa, K., Kis, N., \& Huang, S. (2017). Mastery Motivation in School Subjects in Hungary and Taiwan. Hungarian Educational Research Journal, 7(2), 158-177. https://doi.org/10.14413/HERJ/7/2/10.

Kain, J., Leyton, B., Concha, F., Close, M., Soto-Sánchez, J., \& Salazar, G. (2017). Preschool children's physical activity intensity during school time: Influence of school schedule. Preventive Medicine Reports, 8(March), 6-9. https://doi.org/10.1016/j.pmedr.2017.07.011.

Krisnayanti, N. K. E., Astawan, I. G., \& Renda, N. T. (2020). Positive Influence of Model Guided Inquiry Based on Tri Hita Karana for Learning Motivation and Critical Thinking Skills. Jurnal Pendidikan Dan Pengajaran, 53(2), 101. https://doi.org/10.23887/jpp.v53i2.25121.

Leow, C., \& Wen, X. (2017). Is Full Day Better Than Half Day? A Propensity Score Analysis of the Association Between Head Start Program Intensity and Children's School Performance in Kindergarten. Early Education and Development, 28(2), 224239. https://doi.org/10.1080/10409289.2016.1208600.

Listiningrum, H. D., Tobari, \& Kesumawati, N. (2019). The Principal's strategy for Managing Conflicts due to the Stres dst. International Journal of Educational Review, $1(2), 1-8$.

Løvoll, H. S., Røysamb, E., \& Vitters $\emptyset$, J. (2017). Experiences matter: Positive emotions facilitate intrinsic motivation. Cogent Psychology, 4(1), 1340083. https://doi.org/10.1080/23311908.2017.1340083.

Madjid, A. (2018). Full Day School Policy for Children's Character Development. The Online Journal of New Horison In Education, 8(3), 51-60. http://www.tojned.net/journals/tojned/volumes/tojned-volume08-i03.pdf\#page=58.

Morgan, G. A., Liao, H.-F., Szombathelyiné Nyitrai, Á. A., Huang, S.-Y., Wang, P.-J., \& Józsa, K. (2017). The revised Dimensions of Mastery Questionnaire (DMQ 18) for infants and preschool children with and without risks or delays in Hungary, Taiwan, and the US. Hungarian Educational Research Journal (HERJ), 7(2), 48-67.

Muti'ah, Z. D., \& Sholeh, M. (2020). Pengruh FDS karakter. Inspirasi Manajemen Pendidikan, 8(2), 27-40.

Nelwati, S., Amelia, U., \& Mandasari, M. (2020). An Analysis of Full Day School Policy. International Journal of Education, Information Technology Anf Others (IJEIT), 3(1), 
1-10. https://doi.org/10.5281/zenodo.3735660.

Paramitha, I. D. A. A., Made Sulastri, M. P., \& Margunayasa, I. G. (2016). Pengaruh model inkuiri terbimbing, gaya kognitif, dan motivasi berprestasi terhadap pemahaman konsep IPA siswa kelas V SD. MIMBAR PGSD Undiksha, 4(1). https://doi.org/10.23887/jjpgsd.v4i1.6997.

Putra, D. M. P. D., Ardana, I. M., \& Astawa, I. W. P. (2019). Contribution of mathematics anxiety, achievement motivation, and academic potential to problem solving ability. Jurnal Pendidikan Dan Pengajaran, 52(1), 15-25. https://doi.org/10.23887/jpp.v52i1.17245.

Radyuli, P., Wijaya, I., \& Ulfina, I. (2020). Correlation of Self-Confidence and Student Learning Motivation Against Learning Outcomes of Class X Digital Simulation. Journal of Education Research and Evaluation, 4(2), 216. https://doi.org/10.23887/jere.v4i2.23095.

Rahman, Y. (2018). Pengaruh Manajemen Pembelajaran Full Day School terhadap Motivasi Belajar Siswa. Jurnal Pendidikan Surya Edukasi (JPSE), 4(1), 1-9.

Rahmatika, N., \& Suyatno. (2020). Students' readiness to learn in the a five-day school policy in the public senior high school of yogyakarta. Universal Journal of Educational Research, 8(11), 5005-5014. https://doi.org/10.13189/ujer.2020.081101.

Reynolds, A. J., Richardson, B. A., Hayakawa, M., Lease, E. M., Warner-Richter, M., Englund, M. M., Ou, S. R., \& Sullivan, M. (2014). Association of a full-day vs partday preschool Interventionwith school readiness, attendance, and parent involvement. JAMA - Journal of the American Medical Association, 312(20), 2126-2134. https://doi.org/10.1001/jama.2014.15376.

Rosalina, T. (2012). Pengaruh Manajemen Pembelajaran Full Day School Terhadap Motivasi Belajar. Jurnal Manajemen Pendidikan, 23(5), 434-438. https://www.academia.edu/download/55740037/Jurnal-Manajemen-PendidikanVolume-23-no.-5.pdf\#page $=43$.

Said, A., Slamet, A., \& Prihatin, T. (2018). Full Day School Management Model at SMP Islam Manbaul Hikmah Brebes. Educational Management, 8(1), 26-33. https://journal.unnes.ac.id/sju/index.php/eduman/article/view/28739.

Saptono, L., Soetjipto, B. E., Wahjoedi, \& Wahyono, H. (2020). Role-playing model: Is it effective to improve students' accounting learning motivation and learning achievements? Cakrawala Pendidikan, 39(1), 133-143. https://doi.org/10.21831/cp.v39i1.24781.

Schumm, M. F., \& Bogner, F. X. (2016). Measuring adolescent science motivation. International Journal of Science Education, 38(3), 434-449. https://doi.org/10.1080/09500693.2016.1147659.

Setiawan, A., Widjaja, S. U. M., Kusumajanto, D. D., \& Wahyono, H. (2020). The effect of curriculum 2013 on economics learning achievement: Motivation as mediating variable. Cakrawala Pendidikan, 39(2), 444-459. https://doi.org/10.21831/cp.v39i2.30279.

Singh, K. (2011). Study of achievement motivation in relation to academic achievement of students. International Journal of Educational Planning \& Administration, 1(2), 161171. http://www.ripublication.com/ijepa/ijepav1n2_8.pdf.

Stoeber, J., Childs, J. H., Hayward, J. A., \& Feast, A. R. (2011). Passion and motivation for studying: predicting academic engagement and burnout in university students. Educational Psychology, 31(4), 513-528. 
Surinati, I. D. A. K., Widjanegara, I. G., Suratiah, S., \& Ribek, N. (2020). The Effectiveness of Education to Increase Motivation and Primary Cervical Cancer Prevention Actions. Journal of Education Research and Evaluation, 4(4), 435. https://doi.org/10.23887/jere.v4i4.30045.

Suyatno, S., \& Wantini, W. (2018). Humanizing the Classroom: Praxis of Full Day School System in Indonesia. International Education Studies, 11(4), 115. https://doi.org/10.5539/ies.v11n4p115.

Syafitri, R. (2020). Analysis Students' Perceptions of Full Day School And The Constraints Made In Class V of The Cluster II Elementary School Tampan District Pekanbaru City. Jurnal PAJAR (Pendidikan Dan Pengajaran), 4(5), 917-925.

Tran, T. N. M., \& Pasquier-Doumer, L. (2019). Full-day Schooling and Educational Inequality in Vietnam. Journal of Development Studies, 55(5), 786-804. https://doi.org/10.1080/00220388.2018.1469744.

Utomo, H. B., Suminar, D. R., \& Hamidah. (2019). Capturing teaching motivation of teacher in the disadvantaged areas. Cakrawala Pendidikan, 38(3), 398-410. https://doi.org/10.21831/cp.v38i3.26411.

Wahyuni, P. D., Djatmika, E. T., \& As'sari, A. R. (2018). Pengaruh Full Day School dan Gerakan Literasi Sekolah terhadap Hasil Belajar dengan Mediasi Motivasi Belajar. Jurnal Pendidikan, 3(5), 679-684. https://doi.org/10.17977/jptpp.v3i5.11096.

Winurini, S. (2016). Wacana Penerapan Full day school untuk Siswa SD dan SMP. Majalah Info Singkat Kesejahteraan Sosial, 8(15), 9-12. 